\title{
ERCC1 and the Prognosis for Patients With Colon Cancer Receiving Oxaliplatin-Based Adjuvant Chemotherapy
}

\author{
Moo-Jun Baek \\ Department of Surgery, Soonchunhyang University Cheonan Hospital, Soonchunhyang University College of Medicine, Cheonan, Korea
}

See Article on Page 92-97

Oxaliplatin is known to be a platinum-based chemotherapeutic agent that carries a 1,2-diamino-cyclohexane ring. This drug has shown in vitro and in vivo antitumor activities in patients with colorectal cancer (CRC) [1]. The addition of oxaliplatin to 5FU (FOLFOX regimen) was shown to improve the adjuvant treatment of stage-III colon cancer by reducing the risk of recurrence and increasing overall survival $[2,3]$. Oxaliplatin exerts its action by forming DNA-platinum mono-adducts, primarily with guanines. Oxaliplatin also inhibits DNA replication and transcription and induces apoptosis [1]. Generally, oxaliplatin-induced adducts are not recognized by the mismatch repair system, but are repaired by the nucleotide excision repair and base excision repair pathways [4, 5]. An enhanced DNA repair efficiency may contribute to a resistance to platinum-based cytotoxic drugs. Several studies have demonstrated that single nucleotide polymorphisms involved in DNA repair, such as excision repair cross-complementing group 1 (ERCC1) [6], may predict the clinical outcome for patients receiving oxaliplatin-based chemotherapy for the treatment of CRC. In metastatic $\mathrm{CRC}$, measurements of the ERCC1 and the thymidylate synthase (TS) expressions have potential clinical utility in managing patients, and several studies have addressed the role of ERCC1 in terms of adjuvant colon-cancer treatment.

The authors used immunohistochemical staining in an attempt to identify ERCC1 as a predictive marker for FOLFOX adjuvant chemotherapy in treating patients with stage-II and -III colon cancer [7]. They found that ERCC1 expression was not signifi-

Correspondence to: Moo-Jun Baek, M.D.

Department of Surgery, Soonchunhyang University Cheonan Hospital, Soonchunhyang University College of Medicine, 31 Suncheonhyang 6-gil, Dongnam-gu, Cheonan 330-930, Korea

Tel: +82-41-570-3633, Fax: +82-41-571-0129

E-mail: ssurge@sch.ac.kr

(C) 2015 The Korean Society of Coloproctology

This is an open-access article distributed under the terms of the Creative Commons Attribution NonCommercial License (http://creativecommons.org/licenses/by-nc/3.0) which permits unrestricted noncommercial use, distribution, and reproduction in any medium, provided the original work is properly cited. cantly correlated with the 5 -year disease-free survival as reflected by the oncologic outcomes in patients with high-risk stage-II and -III colon cancer treated with FOLFOX adjuvant chemotherapy. Although the authors could not show any predictive impact of ERCC1, negative results regarding ERCC1 in the era of colon cancer are not unusual, which is the reason a further prospective, large-scale study is needed regarding this issue.

\section{CONFLICT OF INTEREST}

No potential conflict of interest relevant to this article was reported.

\section{REFERENCES}

1. Raymond E, Chaney SG, Taamma A, Cvitkovic E. Oxaliplatin: a review of preclinical and clinical studies. Ann Oncol 1998;9:1053-71.

2. Andre T, Boni C, Mounedji-Boudiaf L, Navarro M, Tabernero J, Hickish T, et al. Oxaliplatin, fluorouracil, and leucovorin as adjuvant treatment for colon cancer. N Engl J Med 2004;350:2343-51.

3. Kuebler JP, Wieand HS, O'Connell MJ, Smith RE, Colangelo LH, Yothers G, et al. Oxaliplatin combined with weekly bolus fluorouracil and leucovorin as surgical adjuvant chemotherapy for stage II and III colon cancer: results from NSABP C-07. J Clin Oncol 2007;25:2198-204.

4. Chaney SG, Campbell SL, Bassett E, Wu Y. Recognition and processing of cisplatin- and oxaliplatin-DNA adducts. Crit Rev Oncol Hematol 2005;53:3-11.

5. Zaanan A, Meunier K, Sangar F, Flejou JF, Praz F. Microsatellite instability in colorectal cancer: from molecular oncogenic mechanisms to clinical implications. Cell Oncol (Dordr) 2011;34:155-76.

6. Yin M, Yan J, Martinez-Balibrea E, Graziano F, Lenz HJ, Kim HJ, et al. ERCC1 and ERCC2 polymorphisms predict clinical outcomes of oxaliplatin-based chemotherapies in gastric and colorectal cancer: a systemic review and meta-analysis. Clin Cancer Res 2011;17:1632-40.

7. Kim CY, Seo SH, An MS, Kim KH, Hwang JW, Kim JH, et al. ERCC1 as a predictive marker for FOLFOX chemotherapy in an adjuvant setting. Ann Coloproctol 2015;31:92-7. 